\title{
Spatial variability in reef fish distribution, abundance, size and biomass: a multi-scale analysis
}

\author{
Nick Gust* ${ }^{*}$ J. Howard Choat, Mark I. McCormick \\ Department of Marine Biology, James Cook University, Townsville, Queensland 4811, Australia
}

\begin{abstract}
This study used underwater visual census techniques to quantify the distribution, abundance, fork lengths and biomass of scarid fishes on multiple reefs across the continental shelf of the northern Great Barrier Reef. Spatial patterns in fish distribution were examined over a cross shelf environmental gradient using a hierarchical sampling design that covered a spectrum of scales ranging from metres to tens of kilometres. The design included replicate reefs within mid and outer continental shelf positions and replicate sheltered and exposed sites within each reef. Most of the 21 species surveyed were found to be widely distributed across mid and outer shelf reefs and the number of species did not change significantly between reefs, exposures or across the shelf. Despite a similar complement of species, scarid assemblages differed markedly in the relative and absolute abundance of taxa between exposed and sheltered habitats on mid and outer shelf reefs. Principal components and cluster analyses indicated that changes in the numerical abundance of taxa resulted in consistently different assemblages from 9 sheltered mid shelf sites and 9 exposed outer shelf sites at opposite ends of the surveyed environmental gradient. Variance components calculated for scarid abundance and biomass across 4 spatial scales revealed differences in the scales at which significant variability occurred between sheltered and exposed reef habitats. On exposed reef crests significant variation occurred at both scales of tens of kilometres (shelf position) and hundreds of metres (sites), while on sheltered back reefs significant variation was attributable only to the site scale. Mean scarid abundance $( \pm \mathrm{SE})$ for exposed outer shelf sites $\left(3060 \pm 460 \mathrm{ha}^{-1}\right)$ was on average 4 times higher than in all other habitat zones surveyed, while mean biomass $\left( \pm\right.$ SE) was only 3 times higher $\left(920 \pm 190 \mathrm{~kg} \mathrm{ha}^{-1}\right)$. The discrepancy between abundance and biomass estimates is explained by a $30 \%$ average decline in parrotfish fork lengths on exposed outer shelf reef crests relative to other habitats. Log-linear analysis indicated that at least 8 species of scarids displayed significant changes in body size according to their location across the continental shelf and/or the prevailing exposure regime. The observed patterns of variation in density and length frequency suggest density-dependent processes and that changes in mortality or growth rates may exist between habitats across the continental shelf.
\end{abstract}

KEY WORDS: Spatial scales $\cdot$ Exposure $\cdot$ Biomass $\cdot$ Environmental gradient $\cdot$ Body size $\cdot$ Tropical reef fish - Resale or republication not permitted without written consent of the publisher

\section{INTRODUCTION}

Coral reef habitats are highly heterogeneous and may be subject to strong environmental gradients that reflect the influence of exposure and reef position relative to coastlines. Consequently reef fishes are seldom uniformly distributed and occur in conspicuous patches over this multi-scalar environment. As the spa-

*E-mail: nick.gust.@hotmail.com tial scales on which organisms are studied have major implications for our understanding of biological processes on coral reefs (Sale 1998), sampling designs that incorporate scale are particularly valuable (Andrew \& Mapstone 1987). Despite the acknowledged importance of such designs in determining patterns of natural variation in the distribution and abundance of reef biota (e.g. Caley et al. 1996), very few studies in the literature have covered more than 3 spatial scales, particularly for reef fishes. The problem of natural spatial 
variability is especially acute for studies which seek to compare undisturbed areas with those subject to anthropogenic disturbances.

The continuous expanse of the Great Barrier Reef (GBR) with strong cross shelf gradients provides an excellent opportunity for exploring the effects of scale dependence in coral reef systems. The GBR marine park is the largest underwater reserve in the world, stretching over $2000 \mathrm{~km}$ and comprising some 2500 individual reefs separated by distances ranging from a few hundred metres to tens of kilometres. Understanding patterns of distribution and abundance of reef organisms among reefs is crucial for managing this system (Hughes et al. 1999). Moreover for many groups of reef species on the GBR anthropogenic disturbance is minimal. These unique circumstances enable investigation of patterns of spatial variation in many species without the complication of direct human disturbance.

Strong latitudinal cross shelf gradients have previously been described across the GBR and were reviewed by Wilkinson \& Cheshire (1988). These authors described changes in salinity, nutrient input, water clarity and exposure to prevailing wind and waves with increasing distance from the coast. They characterised inshore reefs as typically receiving variable freshwater inputs from terrestrial run off which reduced salinity and water clarity in comparison with mid and outer shelf reefs that experience more oceanic conditions, reduced inorganic and organic nutrient inputs, improved light transmittance and higher exposure to wind and waves.

Over the last decade a number of studies have investigated the broad scale distribution and abundance of coral reef biota across the continental shelf of the central GBR that covary with these shifts in abiotic conditions. These studies have described the distribution and abundance of a wide variety of taxa including hard corals (Done 1982), soft corals (Dinesen 1983), holothuroids (Hammond et al. 1985), crustaceans (Preston \& Doherty 1990, 1994), sponges (Wilkinson \& Trott 1985), algae (Scott \& Russ 1987, Klumpp \& McKinnon 1992, McCook et al. 1997) and reef fishes (Williams 1982, 1983, Williams \& Hatcher 1983, Russ 1984a,b, Newman \& Williams 1996, Newman et al. 1997). In each of these studies major cross shelf differences in community structure were demonstrated and, in many cases, differences in the distribution and abundance of individual species were pronounced between shelf locations. In the case of reef fishes, none of these studies have revealed changes in the body sizes of taxa across the continental shelf.

In this study hierarchical or nested sampling was used to measure spatial variation in the numerical abundance and biomass of reef fishes over spatial scales spanning 4 orders of magnitude. The target group were fishes of the Family Scaridae, which are an abundant and functionally important element of coral reef fish communities (Williams \& Hatcher 1983, Choat 1991). These fishes are important targets of reef fisheries in Asia and the Pacific (e.g. Jennings et al. 1995, Jennings \& Polunin 1996, Russ \& Alcala 1998), and increasing human populations suggest increasing exploitation rates in the future. The impetus for this study developed from the observation that a number of fish taxa on reef crests of outer barrier reefs appeared more abundant but smaller than conspecifics on the equivalent mid shelf habitats some $20 \mathrm{~km}$ away (Choat \& Randall 1986). Scarid fishes were important elements of this pattern, with numerous anecdotal accounts of extremely small terminal phase males on outer shelf reef crests exposed to full oceanic influences. As most scarids are protogynous (Choat \& Robertson 1975), this situation provided an opportunity to investigate the influence of spatial scale on the plasticity of growth, sex change and other life history features. The initial step in such an investigation requires the quantification of patterns of size and abundance in the target species. This study provides the framework for the analysis of population dynamics and demography in the species concerned.

The aims of this study were to describe patterns in the distribution, abundance and species richness of scarid fishes over a variety of spatial scales across the continental shelf of the northern GBR. Furthermore, we aimed to determine the length frequency distributions of scarids on replicate reefs in mid and outer continental shelf positions to examine potential shifts in body sizes and biomass associated with this natural environmental gradient.

\section{MATERIALS AND METHODS}

Study species. Scarid fishes are an excellent family to target in a study that examines the influence of environmental gradients on abundance patterns and size structure since they are one of the most abundant and widespread families of reef fishes (Williams \& Hatcher 1983, Choat 1991) and display particularly high local densities (Meekan \& Choat 1997). Adults of the 27 species on the GBR can be identified to species using the criteria of Choat \& Randall (1986) and Randall et al. (1997). In addition parrotfishes show little response to the presence of SCUBA divers, so that underwater visual censusing (UVC) techniques can provide reliable measures of distribution, abundance, population density and biomass (Samoilys \& Carlos 1992). Existing evidence (reviewed by Parrish 1989) also suggests that demersal reef fish such as scarids rarely move between reefs, so that differences between reefs are likely to 
reflect the dynamics of local populations and will not be biased by individuals undertaking cross-shelf ontogenetic migrations. Furthermore, since scarids are not currently harvested on the GBR, differences cross the continental shelf can reasonably be expected to reflect responses to environmental conditions without the potentially confounding direct effects of fishing.

Most species of scarids occur within the size range of 150 to $450 \mathrm{~mm}$ standard length (SL) as adults (Randall et al. 1997), although the very large but rare species Bolbometopon muricatum exceeds $1000 \mathrm{~mm}$ SL. This species tends to be mobile, with schooling producing highly clumped, shifting distribution patterns. In terms of body size, feeding activities (Bellwood \& Choat 1990) and distribution patterns, B. muricatum represents a distinctive component of the scarid fauna which requires different methods for censusing and observation. Pilot studies investigating patterns of $B$. muricatum abundance and distribution suggest that most individuals occur on outer reef fronts at low densities compared to smaller scarids ( 0.87 ind. per $\left.270 \mathrm{~m}^{2}\right)$. The focus of this study is the abundant fauna of smaller scarids, comprising 21 species which occur widely across mid and outer shelf reefs (Russ 1984a,b).

Sampling design. A large-scale visual survey was conducted in December 1996 and February 1997 using 3 reefs in both mid and outer shelf locations as replicate study units (Fig. 1). The $3 \mathrm{mid}$ shelf reefs surveyed (Lizard Island, North and South Direction Islands) were approximately $25 \mathrm{~km}$ from the coast, while the 3 surveyed outer shelf locations (Hicks, Day and Yonge reefs) were approximately $45 \mathrm{~km}$ from the mainland. Hierarchical sampling was adopted since it enables partitioning of variability across a variety of spatial scales and can identify the scales at which important patterns and processes occur (Sale 1998). The sampling design focused on variability at 4 spatial scales: between shelf positions (20 km apart), between reefs within the same shelf position (5 to $10 \mathrm{~km}$ apart), between sites (separated by 100 to $1000 \mathrm{~m}$ ), and variability within sites at scales of tens of metres. Reefs and sites were randomly selected from available localities subject to the logistical constraints of distance from the Lizard Island Research Station and suitable anchorages.
Surveyed habitats consisted of either windward reef crests or the crests and shallow upper slopes of contiguous reef habitats on the leeward side of each reef. Surveyed reef areas were typically less than $5 \mathrm{~m}$ deep and habitats were selected on the basis that Russ (1984a) found that on the GBR they were characterised by the highest scarid abundance and species richness. By surveying preferred scarid habitats, this study concentrated on 4 key zones (mid shelf sheltered, mid shelf exposed, outer shelf sheltered and outer shelf exposed) in order to maximise the statistical power of comparisons among the various spatial scales of interest, and allowed direct comparisons to the findings of Russ $(1984 a, b)$ on the central GBR. Within each reef 3 replicate sites were surveyed on both exposed (windward) and sheltered (leeward) sides to address variability within these important habitat zones. Eastern sides of reefs on the northern GBR are exposed to prevailing southeasterly trade winds, while western sides

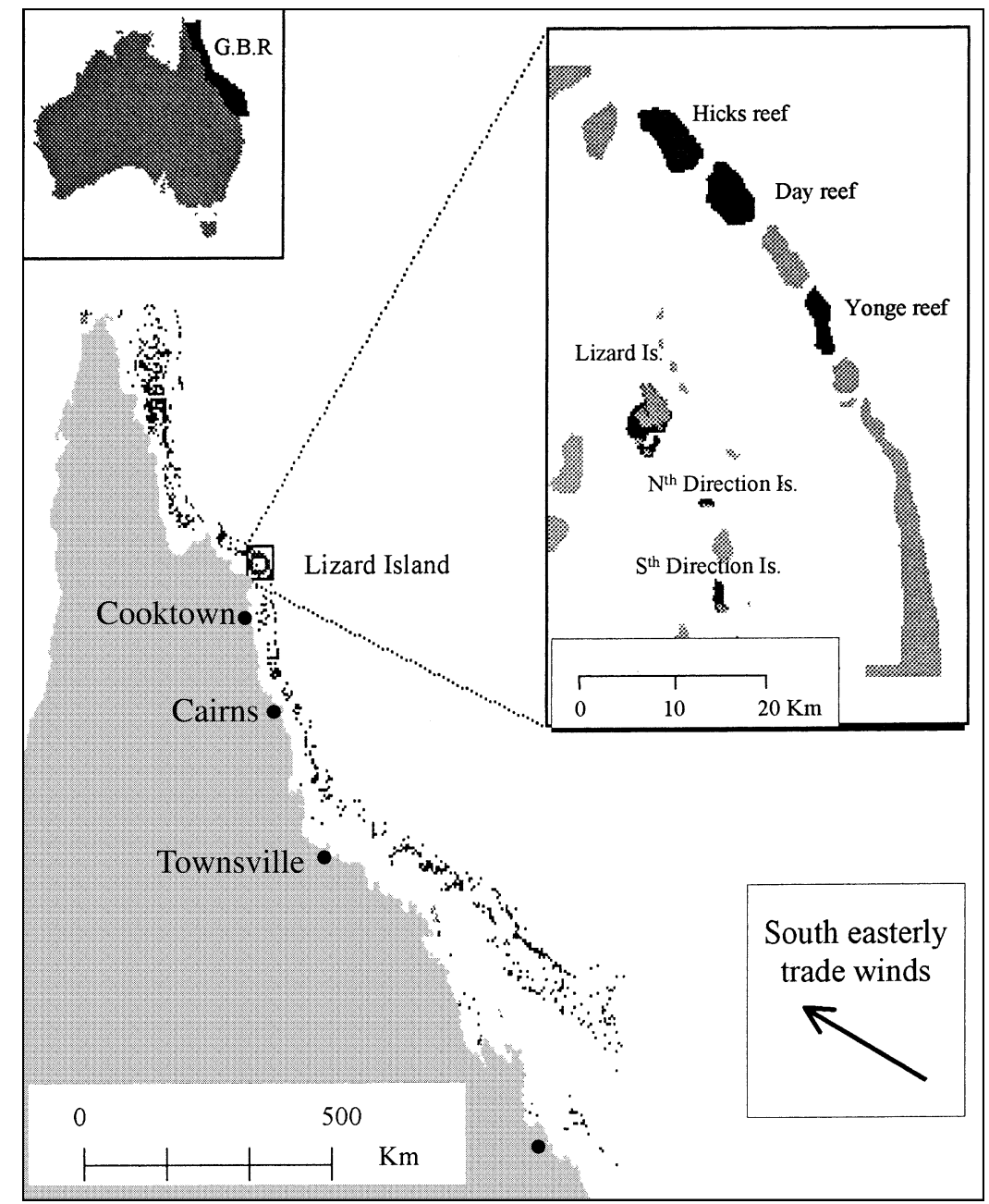

Fig. 1. Position of the 6 reefs surveyed in December 1996 and February 1997 across the continental shelf of the northern Great Barrier Reef (GBR) 
of reefs were generally sheltered from winds and waves. In this region trade winds blow steadily at around 15 knots from the southeast from April to November.

The senior author conducted all UVC surveys on SCUBA in 2 to $7 \mathrm{~m}$ of water at each of the 36 sites. Species abundance data at each site was recorded on water proof data sheets from parrotfish encountered on 6 replicated $45 \times 6 \mathrm{~m}$ transect swims. This transect size was chosen since a study on similar-sized mobile herbivorous fish on the GBR (Hart 1996) compared 4 sizes of sampling units and concluded that $45 \times 6 \mathrm{~m}$ transects gave optimal precision and accuracy for abundance estimates. Individuals were identified to species and their fork lengths estimated to the nearest $4 \mathrm{~cm}$ size class. Individuals were only included in the census if greater than $8 \mathrm{~cm}$ in fork length since the inclusion of small fish during the census of a large transect width may result in errors because of the difficulty in detecting small individuals when surveying large areas (Bellwood \& Alcala 1988). The choice of $8 \mathrm{~cm}$ minimum size for survey inclusion reflected a conservative approach that also aimed to avoid difficulties in identifying small, typically cryptic juvenile scarids that often school together and share common colour patterns (Bellwood \& Choat 1989). Furthermore it was not logistically feasible to simultaneously survey small, cryptic individuals and large, conspicuous adults of these species.

To ensure consistency in length estimates, the fork lengths of 20 wooden parrotfish models were estimated daily underwater prior to commencing surveys. This procedure involved attaching a line in an arc to the substrate with model fish randomly attached. The senior author estimated fork lengths from a distance of approximately $5 \mathrm{~m}$ from the line, and then checked estimates by swimming to the opposite side where lengths were inscribed on each wooden fish. Tests of this procedure indicated that length estimations were generally accurate to within $\pm 1.5 \mathrm{~cm}$, and were characterised by small standard errors (see Fig. 2). Since length estimates were not consistently biased, no corrections were applied to the visual survey data. Bolbometopon muricatum has been excluded from these analyses because reliable estimates of abundance and length could not be obtained via these techniques.

Statistical analyses. To investigate cross shelf changes in scarid assemblages, a principal components analysis (PCA) was calculated for log-transformed abundance data summed at the site level using the 15 most abundant species and a covariance matrix. By removing the 6 least common species (which represented a combined total of less than $1 \%$ of individuals surveyed), problems associated with grouping the 36 sites by virtue of their common absence of rare species were

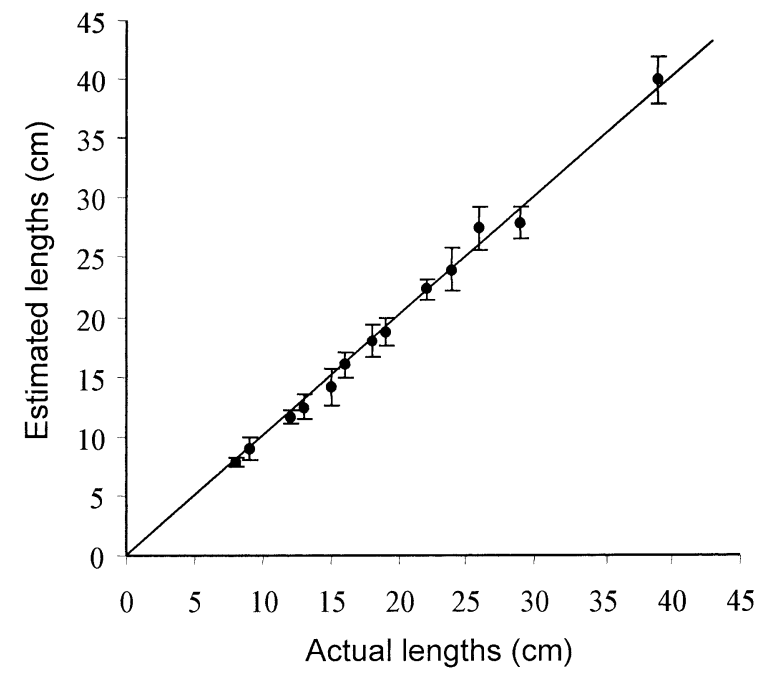

Fig. 2. A comparison of actual and estimated fork lengths of model fishes used to calibrate underwater visual census size estimates. Error bars represent \pm 1 standard error and the fitted line represents an ideal relationship between estimated and actual model fish lengths

greatly reduced. The first 2 principal components were used to examine the patterns of community composition among the 36 sites. A Euclidian bi-plot of species vectors was established to determine the contribution of individual taxa to the multivariate assemblage patterns. Following the PCA, hierarchical cluster analyses on logged abundance data were undertaken to identify major groupings in the assemblage structure suggested by the PCA. A variety of distance measures including Bray-Curtis and Manhattan distance and clustering methods including average linkage, wards and complete linkage clustering were trialed to investigate the consistency of assemblage clustering patterns. Results were broadly consistent among distance measures and the average linkage results for Bray-

Table 1. Length-weight conversions used in biomass calculations. Note that $y=$ weight in $\mathrm{g}$, where $x=$ fork length in $\mathrm{cm}$, $\mathrm{R}^{2}$ is the correlation coefficient for the power curve and $\mathrm{n}$ is the number of individuals used to derive the relationships

\begin{tabular}{|llcr|}
\hline Taxon & $\begin{array}{c}\text { Length-weight } \\
\text { equation }\end{array}$ & $\mathrm{R}^{2}$ & $\mathrm{n}$ \\
\hline All surveyed scarids & $y=0.0181 x^{3.0494}$ & 0.994 & 1078 \\
Chlorurus sordidus & $y=0.0135 x^{3.1638}$ & 0.994 & 240 \\
Scarus frenatus & $y=0.0168 x^{3.0725}$ & 0.994 & 150 \\
S. ghobban & $y=0.0172 x^{3.0627}$ & 0.987 & 20 \\
C. gibbus & $y=0.0161 x^{3.0922}$ & 0.987 & 150 \\
S. niger & $y=0.0155 x^{3.1076}$ & 0.986 & 166 \\
S. psittacus & $y=0.0152 x^{3.1039}$ & 0.990 & 105 \\
S. rivulatus & $y=0.0256 x^{2.947}$ & 0.957 & 35 \\
S. Schlegeli & $y=0.0192 x^{3.008}$ & 0.987 & 62 \\
\hline
\end{tabular}


Curtis distance is presented. Statistical analyses were carried out using SPSS (version 8) and Statistica for Windows (version 4.5).

Abundance and biomass. Biomass estimates were made for each fish by converting UVC length frequency data into equivalent weights (Table 1). The length-weight conversions were derived from scarids collected on the northern GBR. Length-weight conversion equations were species specific for 9 common parrotfish taxa, while for other species a general power curve derived for all scarids was used to convert fork lengths to weights. Weight calculations assumed fish to be the mean length of each $4 \mathrm{~cm}$ size class surveyed.

Initially the number of species, total abundance and biomass estimates were compared among habitat categories across the shelf using a 3-factor mixed-model ANOVA. The model contained terms representing the effects of shelf position (a fixed effect), exposure (also fixed) and reefs as a random nested factor. Transects from each site are pooled in this broad spatial scale analysis. The appropriate tests of each term required a variety of MS error terms and were determined from Quinn \& Keough (in press). Prior to all ANOVA calculations the assumption of homogeneity of variances was inspected via box plots, and $\log (\mathrm{x}+1)$ transformations were used to remove heterogeneity of variances as required.

Inclusion of the orthogonal factors shelf and exposure in the full ANOVA model prevents the calculation of variance components. Therefore to calculate variance components associated with the various spatial scales investigated, exposed windward reef crests and sheltered back reef habitats were examined separately. In both exposure regimes 3-factor fully nested ANOVA designs were tested with shelf position, reefs (shelf), and sites (reefs) as the main factors. Variance components were derived according to Sokal \& Rohlf (1995). Negative variance components for a factor arise when the MS between groups is less than the MS within groups and this suggests that the spatial scale concerned accounts for very little of the overall variance. Negative variance components were converted to zeros as recommended by Brown \& Mosteller (1991).

Size structures. Log-linear modelling was used to test for differences in the length frequency of scarids in response to shelf position, exposure and their interaction effect. Underwater visual censusing data enabled the generation of a multi-way contingency table of scarid length frequencies. In simple terms, log-linear models use logarithmic transformations to analyse multiway frequency tables and provide a systematic method of testing different hypotheses regarding interactions between variables. Specifically, one may think of the multi-way frequency table to reflect various main effects and interaction effects that add together in a linear fashion to bring about the observed table of size frequencies. Shelf position and exposure were both treated as explanatory variables, while fork length was treated as a response variable. A succession of increasingly complex models (Table 2 ) were fitted to the observed data until there were no significant improvements in the goodness-of-fit statistic (deviance or likelihood ratio chi square) from one model to the next. Wrigley (1985) provides a detailed explanation of constructing and testing log-linear models using this method.

\section{RESULTS}

\section{Cross shelf assemblages}

PCA revealed that scarid assemblages differed markedly only between sheltered mid shelf sites and exposed outer shelf sites. The first 2 axes in the PCA (Fig. 3) explained a total of $53 \%$ of the variability in scarid assemblages across the continental shelf, while the third axis represented only an additional $7 \%$ and is not presented. The greatest differences in assemblages were between sites at opposite ends of the surveyed environmental gradient, from sheltered sides of mid shelf reefs and the exposed sides of outer shelf reefs. Much of this difference can be interpreted via the Euclidian 


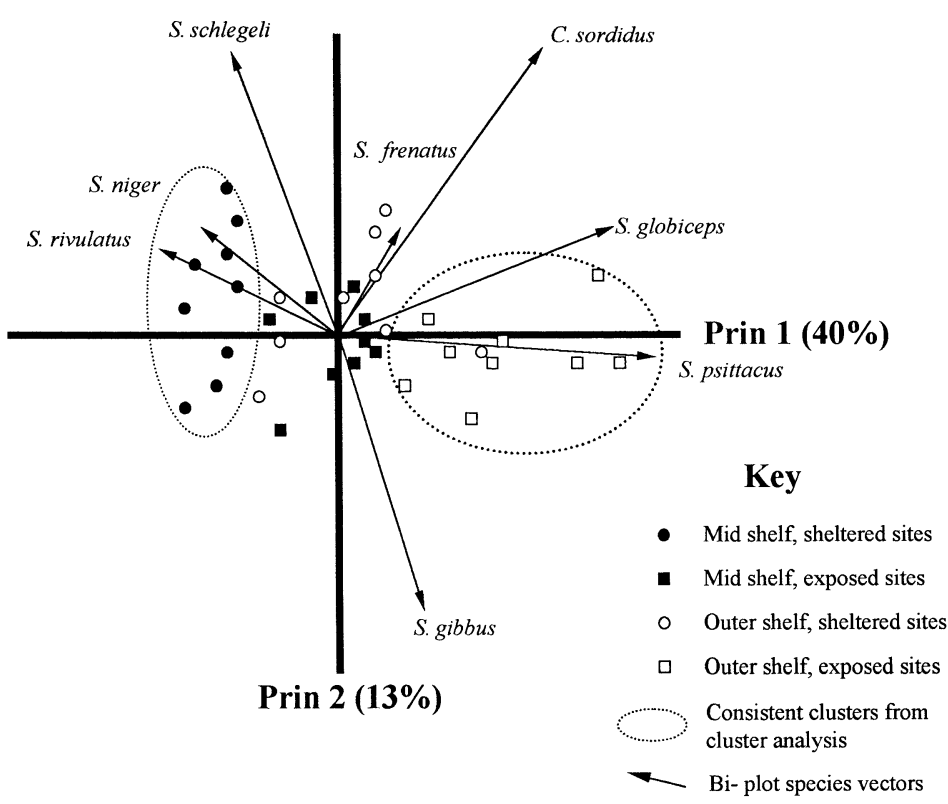

Fig. 3. Results of a principal components analysis on logged abundance of the 15 most common scarid species across the continental shelf. Each of the 36 study sites are plotted in relation to the first 2 principal components axes (Prin 1 and Prin 2) and a bi-plot of species vectors is included to aid interpretation of site groupings. The 2 major clusters of sites identified by cluster analysis are indicated by ellipses. For clarity only the 8 species with important contributions to variability between sites in axes 1 and 2 are indicated

bi-plot of the first 2 principal components (Fig. 3). High abundances of Scarus niger and S. rivulatus were characteristic of the sheltered mid shelf reef sites while these species were either absent or rare on exposed outer reef crests. In contrast, the 9 sites on exposed outer shelf reef crests were characterised by particularly high abundances of $S$. globiceps and $S$. psittacus.

Mid shelf exposed sites and outer shelf sheltered sites displayed similar scarid assemblages and these 18 sites were not clearly divided by either the PCA (Fig. 3) or cluster analysis (Fig. 4). Average and complete linkage clustering methods on Bray-Curtis, Wards and Manhattan distance matrices resulted in a wide variety of groupings of mid shelf exposed and outer shelf sheltered sites. This indicates no pronounced differences in parrotfish assemblages between these 2 habitat zones. In contrast cluster analyses consistently identified 2 zones as having distinct scarid assemblages. The 9 mid shelf sheltered sites were identified as being the most dissimilar cluster, and the 9 outer shelf exposed sites were also clearly a distinct grouping (Fig. 4). It should also be noted that a single outer shelf sheltered site from Day reef often clustered with outer shelf exposed sites, as indicated in Fig. 3. This result reflects the unusually high numbers of Scarus psittacus and S. globiceps which occurred in this back reef site.

\section{Distribution and abundance of species}

Scarid species were typically widely distributed across the continental shelf, although their abundances varied greatly with both shelf position and exposure among the 4 major zones surveyed (Figs. $5 \& 6)$. Within each zone, assemblages were characterised by a few abundant and many rarer species, such that abundances were approximately log normally distributed between species. Assemblages in each zone were species rich, typically including around 20 of the 27 scarid species recorded on the GBR by Choat \& Randall (1986). Furthermore there was no evidence of significant changes in the number of species between reefs within the same shelf position, or with changing exposure or distance from the coast (Table 3 ).

Widely distributed species varied considerably in abundance between habitat zones. For instance Chlorurus sordidus, Scarus frenatus and S. globiceps displayed consistently high abundances at sites across the northern continental shelf, while $S$. altipinnis and $S$. chameleon displayed medium densities and $S$. dimidiatus, $S$. oviceps and $S$. spinus displayed consistently low densities in each of the 4 major habitat zones surveyed (Figs. 5 \& 6). Instances of restricted distributions also existed, where Scarus rivulatus was largely restricted to mid shelf reefs, and S. flavipectoralis was only recorded from the sheltered sides of mid and outer shelf reefs. Individual species varied in mean abundance across the continental shelf by at most 2 orders of magnitude, and considerable changes are evident in both the relative and absolute densities of most scarids across this environmental gradient (Figs. 5 \& 6). C. sordidus was consistently the most

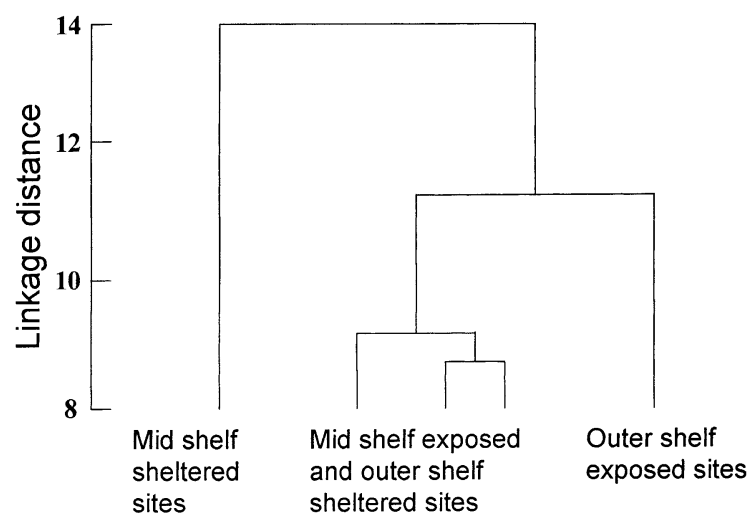

Fig. 4. Dendrogram produced from a hierarchical cluster analysis using log-transformed abundance of the 15 most common scarid species, Bray-Curtis distance and the average linkage method. The most dissimilar clusters diverge initially at the top of this vertical icicle plot 

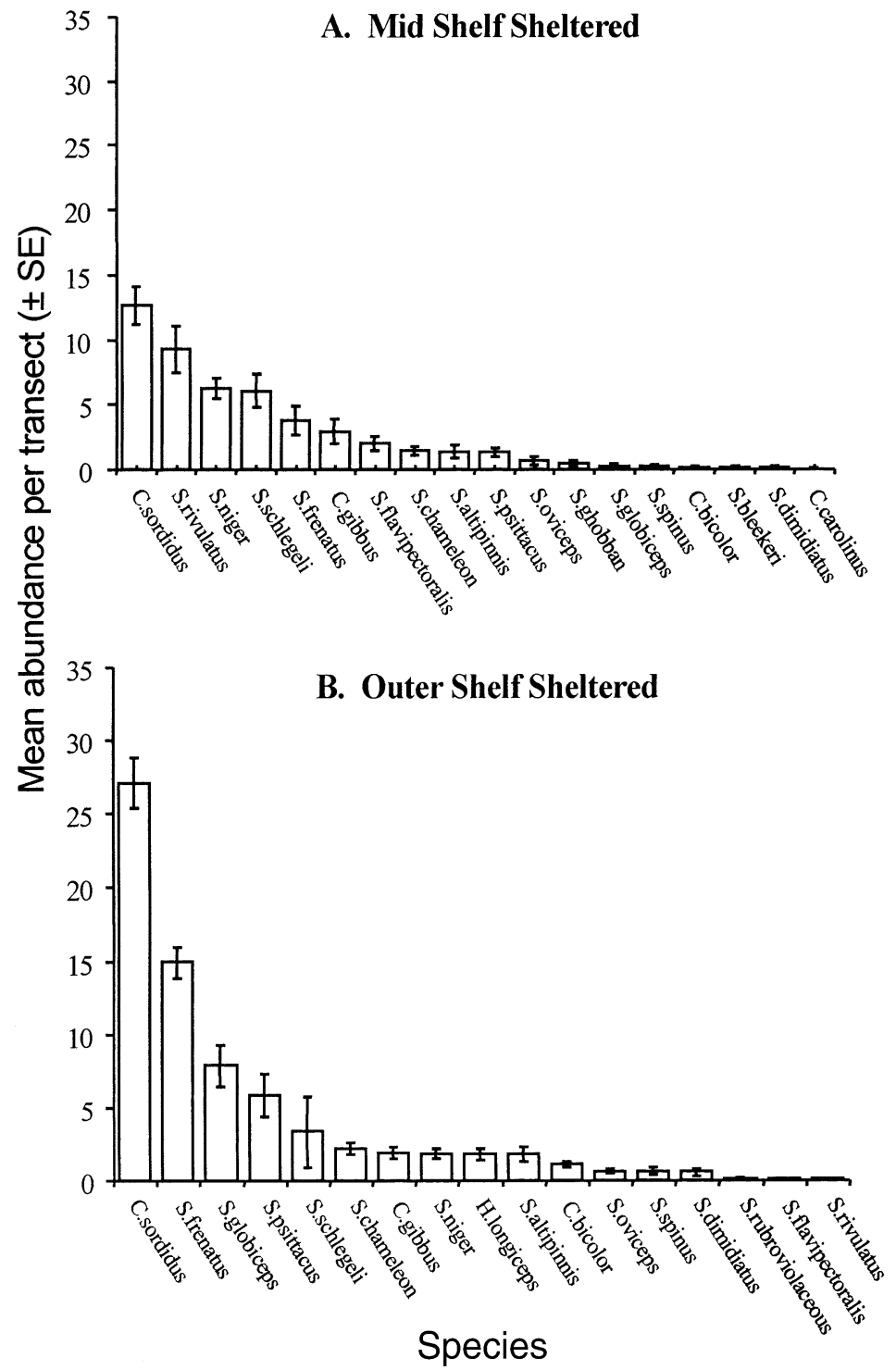

Fig. 5. Mean scarid abundances per transect $( \pm$ SE) on $(A)$ mid shelf sheltered sites and (B) outer shelf sheltered sites. Histograms represent mean abundance per $270 \mathrm{~m}^{2}$ averaged across 3 reefs, 9 sites and 54 transects curred with changing shelf position and exposure, although no significant differences existed between reefs nested within shelf position (Tables 4 \& 5, Fig. 7). A significant reef (shelf) $\times$ exposure interaction term existed for both scarid abundance and biomass, and reflects the particularly high numbers of individuals censused from the 3 exposed sites on Yonge reef. Total scarid abundance estimates were similar amongst 3 of the 4 major zones (sheltered and exposed mid shelf reef sites and sheltered outer shelf sites) with mean abundances of between 15 and 30 ind. per $270 \mathrm{~m}^{2}$ transect (Fig. 7A). In comparison exposed reef crests on outer shelf reefs displayed approximately 4 times higher abundances with means of 70 to 100 ind. transect $^{-1}$ (Fig. 7A). Mean biomass estimates between the 4 surveyed zones (Fig. 7B) broadly reflected numerical abundance estimates and ranged from 3 to $40 \mathrm{~kg}$ transect ${ }^{-1}$ or 11 to $148 \mathrm{~g} \mathrm{~m}^{-2}$. In comparison with other zones, exposed outer shelf reefs displayed approximately a 4 -fold increase in numerical abundance, but only a 3-fold increase in biomass. This difference can be explained by the reduced body sizes of many species on exposed outer shelf reef crests (see 'Results: Body sizes cross shelf').

Components of variation calculated at 4 spatial scales are summarised in Fig. 8 along with significant nested ANOVA results. This figure indicates that scales of significant spatial variability in the abundance and biomass of scarids differed between exposed and sheltered reef habitats. Exposed reef habitats (Fig. 8A,B) displayed significant spatial variability associated with both the shelf scale (tens of kilometres) and the site scale (hundreds of metres). In contrast sheltered reef habitats (Fig. 8C,D) only displayed significant spatial variability at the site scale. There was also evidence of large but non-significant within-site variation on sheltered reefs, where around 50 to $60 \%$ of total variation in abundance and biomass ex- abundant scarid in 3 of the 4 surveyed habitat zones in this region, although the highest recorded mean densities for any species existed for $S$. psittacus $\left(136 \pm 35\right.$ se per $\left.270 \mathrm{~m}^{2}\right)$ on exposed outer shelf reef crests (Fig. 6).

\section{Cross shelf abundance and biomass}

Significant changes in the total abundance and biomass of scarids oc-
Table 3. A 3-factor ANOVA showing the influence of shelf position, reef within shelf position and exposure on the number of scarid species across the northern continental shelf. ${ }^{*} \mathrm{p}<0.05 i^{* *} \mathrm{p}<0.01{ }^{* * *} \mathrm{p}<0.001$

\begin{tabular}{|lrrrrrr|}
\hline Source of variation & $\begin{array}{c}\text { MS } \\
\text { effect }\end{array}$ & $\begin{array}{c}\mathrm{df} \\
\text { effect }\end{array}$ & $\begin{array}{c}\text { MS } \\
\text { error }\end{array}$ & $\begin{array}{r}\text { df } \\
\text { error }\end{array}$ & $F$ & $\mathrm{p}$ \\
\hline Shelf & 0.0185 & 1 & 6.6018 & 4 & 0.003 & 0.960 \\
Reef (Shelf) & 6.6018 & 4 & 2.8421 & 204 & 2.32 & 0.058 \\
Exposure & 2.2407 & 1 & 7.5185 & 4 & 0.298 & 0.614 \\
Shelf $\times$ Exposure & 3.6296 & 1 & 7.5185 & 4 & 0.482 & 0.525 \\
Reef (Shelf) $\times$ Exposure & 7.5185 & 4 & 2.8420 & 204 & 2.64 & $0.034^{*}$ \\
Residual & 2.8420 & & & & & \\
\hline
\end{tabular}


Table 4. A 3-factor ANOVA showing the influence of shelf position, reef within shelf position and exposure on the abundance of scarids (log transformed) across the northern continental shelf. $\left({ }^{*} \mathrm{p}<0.05 i^{* *} \mathrm{p}<0.01{ }^{* * *} \mathrm{p}<0.001\right)$

\begin{tabular}{|lrrrrrr|}
\hline Source of variation & $\begin{array}{c}\text { MS } \\
\text { effect }\end{array}$ & $\begin{array}{c}\mathrm{df} \\
\text { effect }\end{array}$ & $\begin{array}{c}\text { MS } \\
\text { error }\end{array}$ & $\begin{array}{c}\text { df } \\
\text { error }\end{array}$ & $F$ & $\mathrm{p}$ \\
\hline Shelf & 1 & 4.766 & 4 & 0.059 & 80.635 & $0.0009^{* * *}$ \\
Reef (Shelf) & 4 & 0.059 & 204 & 0.110 & 0.536 & 0.7093 \\
Exposure & 1 & 3.842 & 4 & 0.391 & 9.834 & $0.0349^{*}$ \\
Shelf $\times$ Exposure & 1 & 0.664 & 4 & 0.391 & 1.699 & 0.2623 \\
Reef (Shelf) $\times$ Exposure & 4 & 0.391 & 204 & 0.110 & 3.543 & $0.0081^{* *}$ \\
Residual & 204 & 0.110 & & & & \\
\end{tabular}

isted between transects at the scale of tens of metres. Replicate reefs within each shelf position contributed a negligible amount to variation in abundance and biomass irrespective of exposure regime.

\section{Body sizes cross shelf}

A statistically significant difference existed in the size frequency (fork lengths) of scarids according to shelf

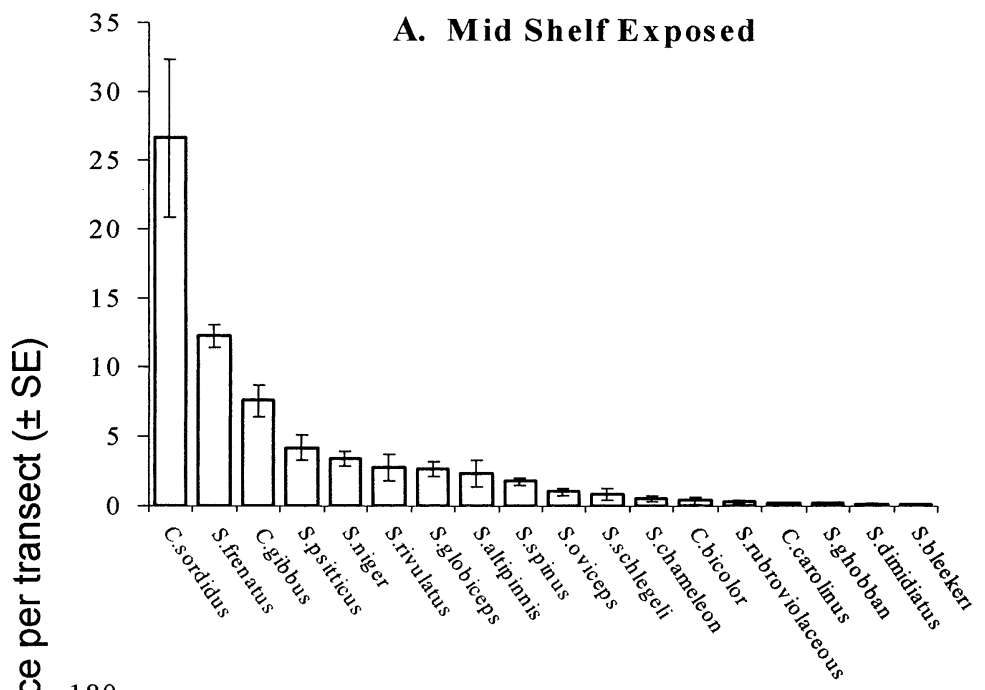

B. Outer Shelf Exposed

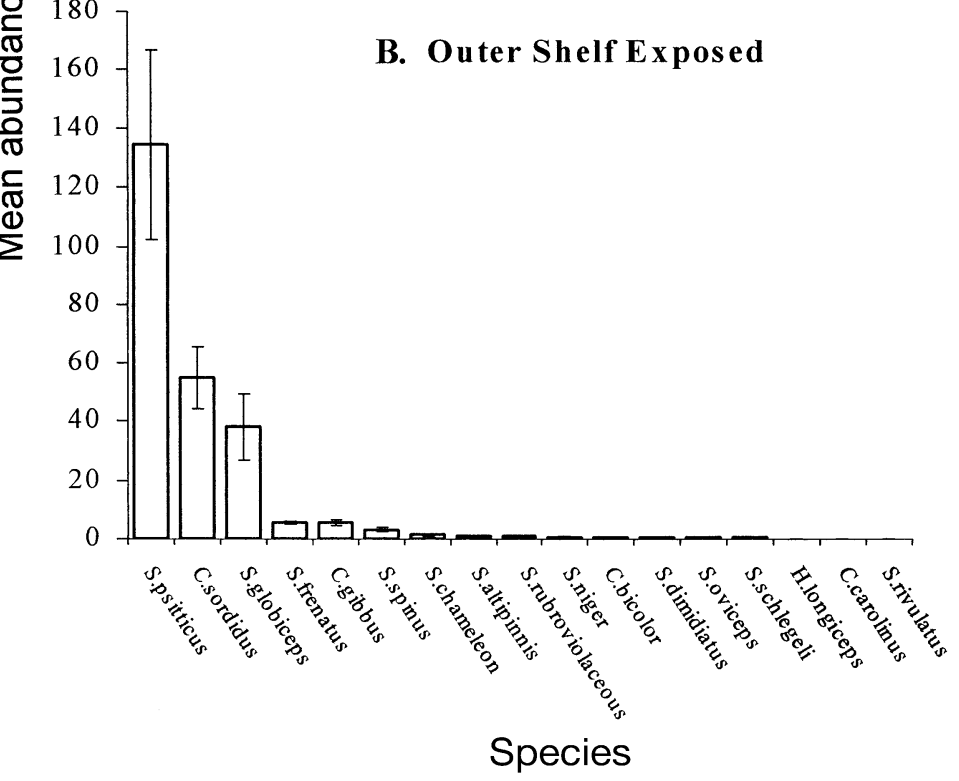

Fig. 6. Mean scarid abundances per transect $( \pm \mathrm{SE})$ on $(A)$ mid shelf exposed reef crest sites and (B) outer shelf exposed reef crest sites. Histograms represent mean abundance per $270 \mathrm{~m}^{2}$ averaged across 3 reefs, 9 sites and 54 transects. To accommodate high values, the abundance scale for (B) is 5 times larger than that shown for the other habitats in Figs. $5 \& 6$ position and exposure across the continental shelf of the northern GBR (Table 6, and see Fig. 9). The most marked difference existed for exposed outer shelf reefs, where over $95 \%$ of surveyed individuals were distributed in the 4 smallest length categories. By contrast the 3 other major zones displayed a more even distribution of length frequencies, with the vast majority of individuals spread throughout seven $4 \mathrm{~cm}$ fork length categories (Fig. 9). This cross shelf pattern is also apparent if we simply consider the mean fork lengths of all scarids surveyed in the 4 habitat zones. Mean scarid fork lengths for mid shelf sheltered, mid shelf exposed and outer shelf sheltered sites were $22.1,21.6$ and $20.8 \mathrm{~cm}$ respectively. In contrast, the average fork length of all parrotfish on outer shelf exposed sites was only $15.0 \mathrm{~cm}$. This represents an average $30 \%$ decline in fork length for scarids in this habitat. The percentage contribution of each size class is presented for each reef and exposure combination (Fig. 10), and indicates that differences in the length frequency of assemblages between replicate reefs within shelf position and exposure categories was small compared with cross shelf trends.

Log-linear analysis revealed a variety of speciesspecific patterns in body size across the continental shelf in response to shelf position and/or exposure (Table 7). Sufficiently large sample sizes existed to test length frequencies in 9 species, 8 of which showed evidence of reduced fork length on outer shelf reefs. This response was most marked for exposed outer shelf habitats, where length frequencies were markedly smaller in 5 species (Chlorurus sordidus, Scarus frenatus, S. globiceps, S. niger and $S$. psittacus). Three additional species ( $S$. chameleon, S. schlegeli and S. spinus) displayed more complex patterns of length frequency distribution across the northern continental shelf. Log-linear analysis revealed that fork length in S. chameleon and $S$. schlegeli was best explained by shelf position alone (Model 3), and in both cases length was 
reduced on the outer shelf regardless of exposure to prevailing trade winds. In contrast Table 7 indicates that $S$. spinus length frequency was best explained by Model 4, which suggests that although there is no significant shelf by exposure interaction, both shelf position and exposure independently influence fork length in this species. Only 1 species (Scarus altipinnis) showed no evidence of changing length frequency across the surveyed habitats, although this result may be compromised by the small sample size available.
Table 5. A 3-factor ANOVA showing the influence of shelf position, reef within shelf position and exposure on scarid biomass (log transformed) across the northern continental shelf. $\left({ }^{*} \mathrm{p}<0.05,{ }^{* *} \mathrm{p}<0.01,{ }^{* * *} \mathrm{p}<0.001\right)$

\begin{tabular}{|lccrrrr|}
\hline Source of variation & $\begin{array}{c}\mathrm{df} \\
\text { effect }\end{array}$ & $\begin{array}{c}\text { MS } \\
\text { effect }\end{array}$ & $\begin{array}{c}\text { df } \\
\text { error }\end{array}$ & $\begin{array}{c}\text { MS } \\
\text { error }\end{array}$ & $F$ & $\mathrm{p}$ \\
\hline Shelf & 1 & 3.119 & 4 & 0.207 & 15.006 & $0.0179^{*}$ \\
Reef (Shelf) & 4 & 0.208 & 204 & 0.116 & 1.783 & 0.1334 \\
Exposure & 1 & 6.296 & 4 & 0.567 & 11.103 & $0.0290^{*}$ \\
Shelf $\times$ Exposure & 1 & 0.381 & 4 & 0.567 & 0.672 & 0.4583 \\
Reef (Shelf) $\times$ Exposure & 4 & 0.567 & 204 & 0.116 & 4.866 & $0.0009^{* * *}$ \\
Residual & & 0.116 & & & & \\
\hline
\end{tabular}

\section{DISCUSSION}

This multi-scale study found that most scarid taxa were widely distributed among replicate reefs in mid
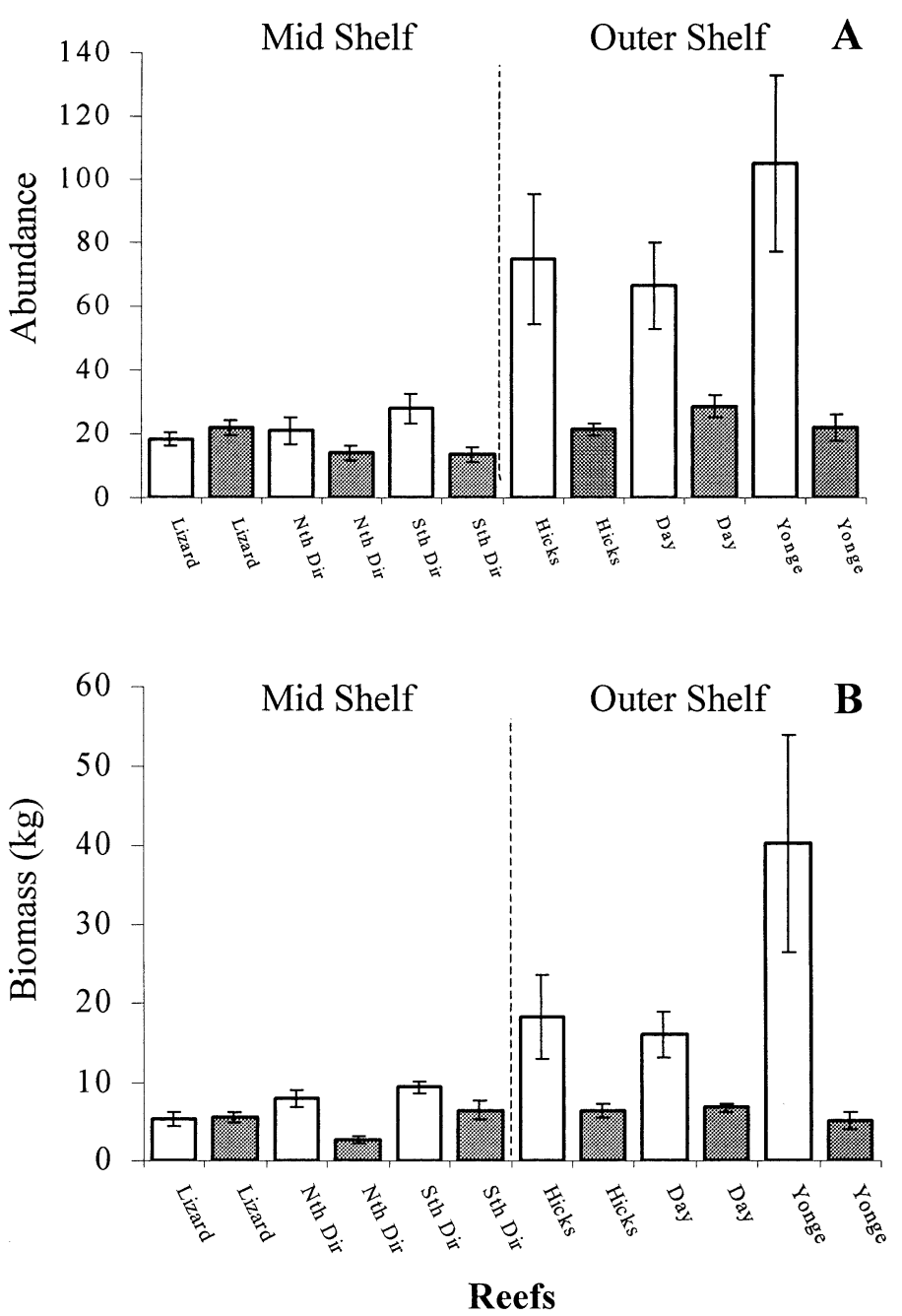

Fig. 7. (A) Mean abundance of all scarids per $270 \mathrm{~m}^{2}$ transect $\left( \pm\right.$ SE). (B) Mean biomass of all scarids per $270 \mathrm{~m}^{2}$ transect $( \pm \mathrm{SE})$. Open bars: exposed reef crests; shaded bars: sheltered back reef habitats and outer continental shelf positions, and a similar species pool was shared between the 4 major habitats surveyed (mid shelf sheltered, mid shelf exposed, outer shelf sheltered and outer shelf exposed). The only evidence of restricted distributions existed for Scarus rivulatus, which was largely confined to mid shelf reefs, and S. flavipectoralis, which was only recorded from sheltered reef sites regardless of shelf position. Although a similar complement of species occurred at sites on the exposed and sheltered sides of mid and outer shelf reefs, there were marked differences in the absolute and relative abundance of key taxa between the most sheltered and most exposed sites. Individual taxa varied in numerical abundance between habitats by up to 2 orders of magnitude.

Scarid assemblages from shallow reef habitats at opposite ends of the surveyed environmental gradient (approximately $20 \mathrm{~km}$ apart) were characterised by major changes in the abundance of 4 taxa. Sheltered mid shelf sites displayed high abundances of both Scarus niger and $S$. rivulatus while outer shelf exposed reef crests were characterised by high numbers of both S. psittacus and S. globiceps. Multivariate analyses confirmed that only assemblages on exposed outer shelf reef crests and sheltered mid shelf reef habitats were distinctively different. The cross shelf patterns of distribution and abundance described in this study are unlikely to result from cross shelf movement associated with ontogeny, which was suggested for some species of lutjanids (Williams 1991), although detailed studies of scarid movement patterns have yet to be undertaken on the GBR.

On the northern GBR significant spatial variability existed in the numerical abundance and biomass of scarids on exposed reef crests at both the cross shelf scale of tens of kilometres and the between site scale of hundreds to thousands of metres. In comparison, sig- 
A. Abundance, exposed reef crests

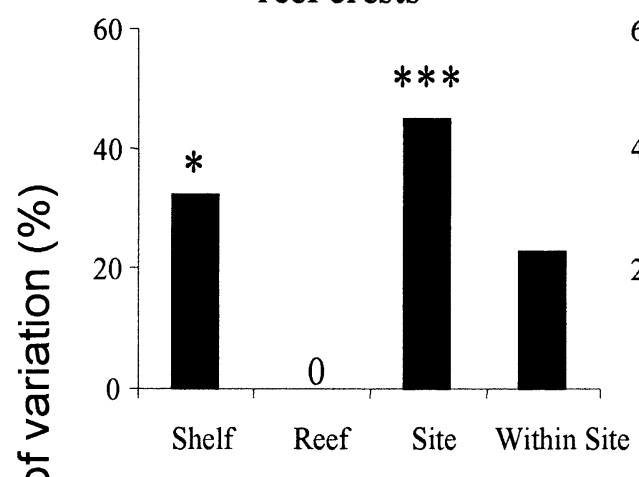

B. Biomass, exposed reef crests

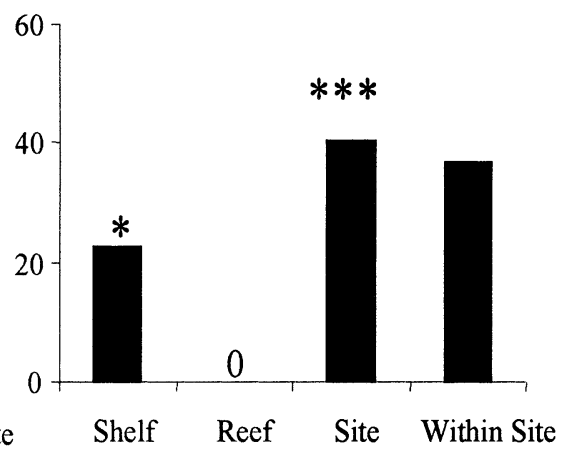

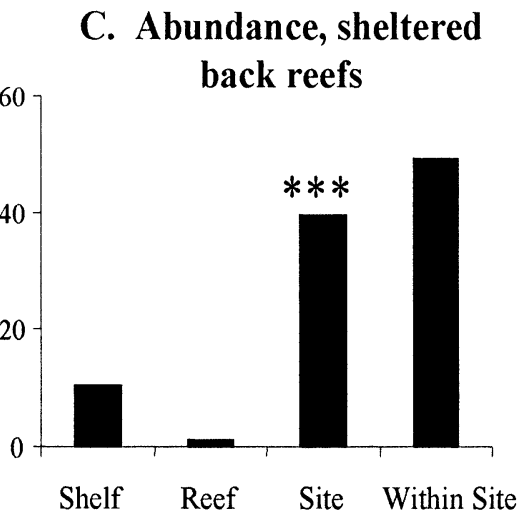

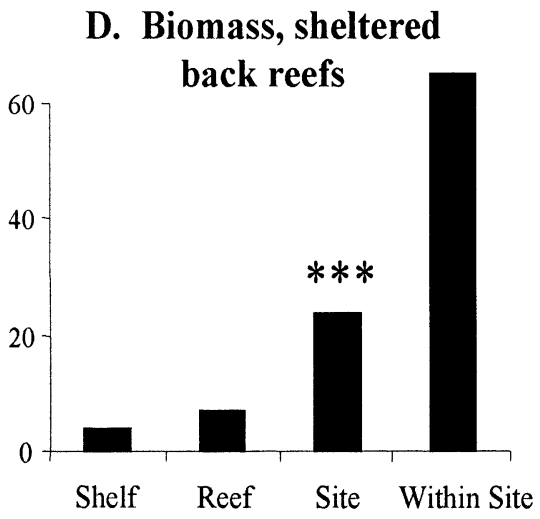

Fig. 8. Components of variation at 4 spatial scales. Variation in (A) abundance and (B) biomass on exposed reef crests, and (C) abundance and (D) biomass on sheltered back reef habitats. Overall variation is partitioned among scales and expressed as a percentage of the total. Negative variance components were converted to zeros. Bars with asterisks indicate the spatial scales where there is significant variation, i.e. where substantial differences occurred among shelf positions, reefs, sites or within sites. $(* \mathrm{p}<0.05$; ** $\mathrm{p}<0.01$; $* * * p<0.001)$

nificant variability in abundance and biomass on back reef habitats was only apparent between sites. Thus it appears that important processes influencing the abundance of scarids varies between exposure regimes cross shelf in this region. On exposed reef crests scarid numbers and biomass varied considerably at all spatial scales investigated except among replicate reefs within the same shelf position. Similarly, on sheltered back reef habitats only $3 \%$ of total variability in numerical abundance and $7 \%$ of total variability in

Table 6. Log-linear analysis of relationships between shelf position, exposure and length frequencies of scarid assemblages across the continental shelf. The most appropriate model is in bold. A total of 7833 fish length estimates were used in these analyses. $\left({ }^{*} p<0.05,{ }^{* *} p<0.01,{ }^{* * *} p<0.001\right)$. A = Shelf position, $\mathrm{B}=$ Exposure, $\mathrm{C}=$ Fork length

\begin{tabular}{|c|c|c|c|c|c|}
\hline Model & Factors included & Deviance & $\mathrm{df}$ & $\begin{array}{c}\text { Difference } \\
\text { between models }\end{array}$ & $\begin{array}{l}\text { Change } \\
\text { in df }\end{array}$ \\
\hline 1 & $\mathrm{~A} \times \mathrm{B}+\mathrm{C}$ & 2679 & 36 & $(1 \& 2) 1372^{* * *}$ & 12 \\
\hline 2 & $\mathrm{~A} \times \mathrm{B}+\mathrm{B} \times \mathrm{C}$ & 1307 & 24 & $(1 \& 3) 1205^{* * *}$ & 12 \\
\hline 3 & $\mathrm{~A} \times \mathrm{B}+\mathrm{A} \times \mathrm{C}$ & 1474 & 24 & $(2 \& 4) 1105^{* * *}$ & 12 \\
\hline 4 & $\mathrm{~A} \times \mathrm{B}+\mathrm{A} \times \mathrm{C}+\mathrm{B} \times \mathrm{C}$ & C 369 & 12 & $(4 \& 5) \quad 369^{* * *}$ & 12 \\
\hline 5 & $\mathbf{A} \times \mathbf{B} \times \mathbf{C}$ & 0.0 & 0 & & \\
\hline
\end{tabular}

biomass could be attributed to the reef scale. Interestingly, Hughes et al. (1999) also found this scale failed to account for significant variability in scleractinian coral abundance on the GBR. Together these studies suggest that future investigations of patterns of distribution in reef organisms on the GBR would benefit from reduced replication of reefs within shelf positions, but increased replication at the site level.

The distribution and abundance of species documented in this study across the continental shelf are broadly comparable with the findings of Russ $(1984 a, b)$ on the central GBR. Both studies described a similar species list of the most abundant scarids, found no evidence of changing numbers of scarid species across the continental shelf and found that most scarid taxa were widely distributed between mid and outer shelf reefs. Nevertheless one major difference existed between these studies. The present study described significant changes in scarid numerical abundance between habitats across the continental shelf. On the northern GBR the mean abundances of scarids on outer shelf 
reef crests were 4 -fold higher than from equivalent reef crest habitats on mid shelf reefs. In contrast Russ $(1984 a, b)$ found no marked changes in the numerical abundance of scarid assemblages between habitats across the shelf of the central GBR.

There are 2 possible explanations for this apparent discrepancy. Firstly it may be that patterns of scarid abundance differ considerably between mid and outer continental shelf positions on the central and northern
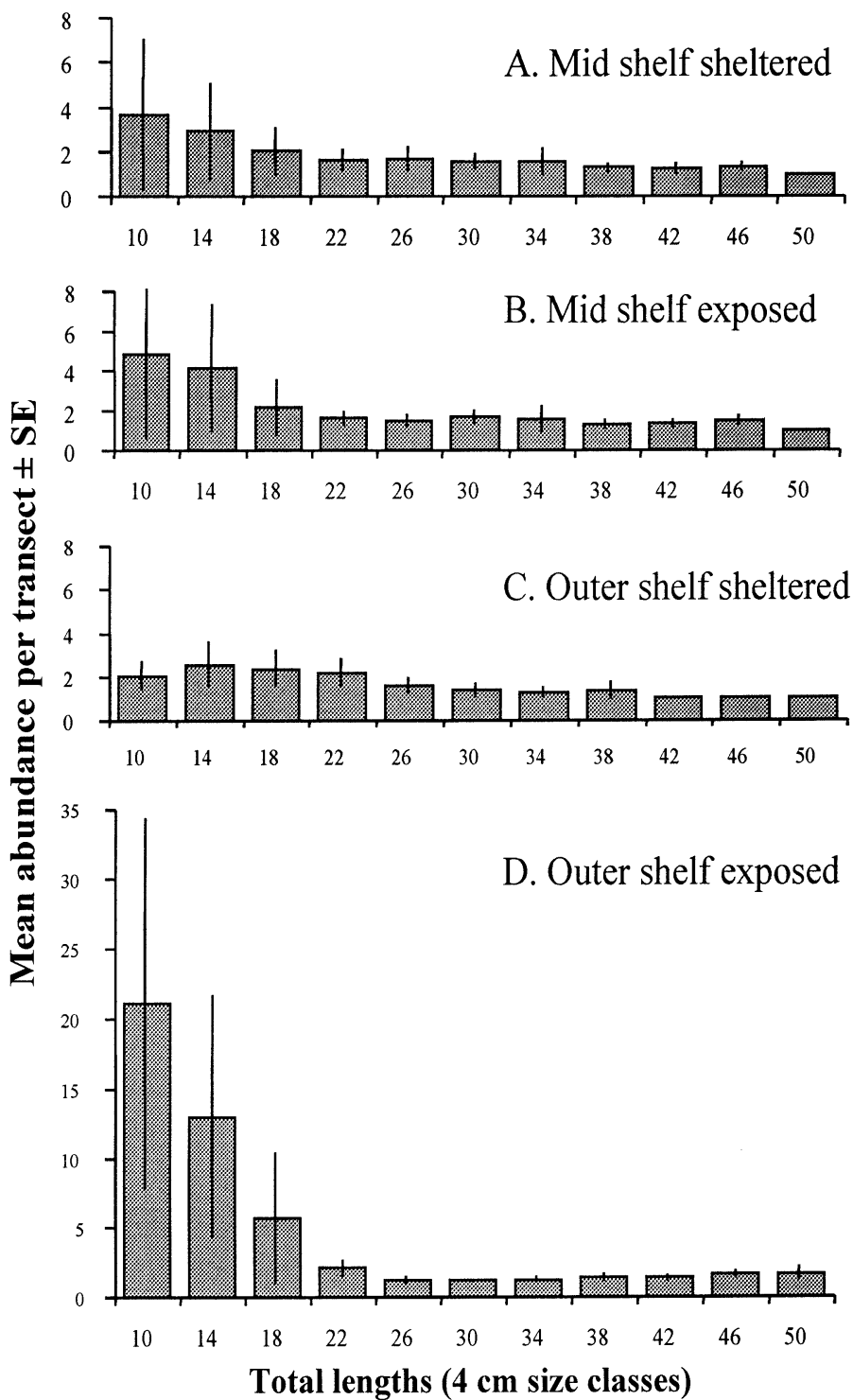

Fig. 9. Size frequency distributions for all scarid species surveyed from (A) mid shelf sheltered sites, (B) mid shelf exposed sites, (C) outer shelf sheltered and (D) outer shelf exposed sites. Means of each $4 \mathrm{~cm}$ size class are represented on the $x$-axis, and the $y$-axis represents the total abundance of scarids derived from 9 sites on either the sheltered or exposed sides of each reef. Note that the scale for (D) is 4 times larger than in the other panels
GBR. The second possibility is that differences in methodology adopted by the 2 studies explain the differences in observed patterns. More specifically the discrepancy between studies may simply reflect the different surveying techniques adopted and varying statistical power to detect changes in numerical abundance. The present study benefited from censusing individuals along replicate transects, while the use of log abundance categories for visual surveys (Russ $1984 a, b)$ may have reduced the power to detect spatial changes in abundance, a point recently acknowledged by the author (Russ \& Alcala 1998).

Mean scarid biomass estimates in this study were similar from 3 of the 4 major habitats surveyed (values ranged from 11 to $40 \mathrm{~g} \mathrm{~m}^{-2}$ ), but were significantly higher for exposed outer shelf reef crests, where mean biomass varied from 70 to $150 \mathrm{~g} \mathrm{~m}^{-2}$. These values are up to an order of magnitude higher than those previously reported for the family from reefs in the Philippines, Seychelles and Fiji. In the Philippines, estimates of the standing stock of scarids varied between locations and researchers. On Apo island reported values varied from 4 to $5.5 \mathrm{~g} \mathrm{~m}^{-2}$, while on Pamilacan island they varied from 3.4 and $4.6 \mathrm{~g} \mathrm{~m}^{-2}$ (Bellwood \& Alcala 1988), and on Sumilon island scarid biomass varied from 7.9 and $9.2 \mathrm{~g} \mathrm{~m}^{-2}$ (Russ 1985). Published biomass estimates from marine parks in the Seychelles (Jennings et al. 1996) varied between 10 and $22 \mathrm{~g} \mathrm{~m}^{-2}$, while mean scarid biomass from 6 localities in Fiji were found to be between 4 and $6 \mathrm{~g} \mathrm{~m}^{-2}$ (Jennings \& Polunin 1996). Thus parrotfish biomass on the northern GBR appears exceptionally high, especially on outer shelf exposed reef crests.

It is clear that reef fish taxa vary in abundance and distribution over a variety of spatial scales. However, to date, few studies on coral reefs have also identified the magnitude of natural variability in reef fish body sizes. This may compromise our ability to detect anthropogenic impacts such as fishing if the simplistic assumption of uniform body sizes in reef fish taxa with wide distributions is accepted. This study provides the first detailed evidence of differences in the length frequency and body sizes of a family of reef fishes across the continental shelf of the GBR. Differences in body size were pronounced. On exposed outer shelf reef crests the average fork length of scarids declined by $30 \%$ in comparison with other habitat zones 1 to $20 \mathrm{~km}$ away. Furthermore these changes in fork length correspond to much larger changes in body weight, since weight is typically a cubic relationship of length in teleosts. Such natural variability in the body size of reef fishes has rarely been demonstrated in habitats of the same depth, although past studies have identified changes in fish sizes associated with water depth (e.g. Clarke 1977), or reef profile (Chabanet \& Letourneur 1995). 
Cross shelf differences in fork lengths cannot be explained by simple sampling artefacts since daily validation with wooden fish models enabled accurate size estimates to be made. This procedure minimised the likelihood of sampling biases between days or sites which has been cited as a significant source of error in previous studies using underwater visual surveys (Bell et al. 1985, St. John et al. 1990). Log-linear modelling indicated that the size of at least 8 species changed with shelf position and exposure regime. In 5 of these species a significant reduction in fork lengths occurred on outer shelf exposed reef crests. These size reductions could have arisen from a variety of variable processes across the continental shelf. For instance reduced size on outer shelf reef crests may reflect density-dependent growth and the influence of exceptionally high scarid densities, or differences in growth rates resulting from different habitat associations across the continental shelf. It is also possible that reduced fork lengths in these habitats may reflect higher mortality regimes and higher recruitment rates such that local populations on outer shelf reef crests are dominated by larger proportions of smaller, younger individuals. These potentials are currently under investigation.

Described changes in the body size of scarids across the continental shelf are likely to have major implications for the way individuals interact with their environment (as reviewed by Werner \& Gilliam 1984). Specifically, body size is known to impose important energetic constraints on individual fishes and affects resource ex-

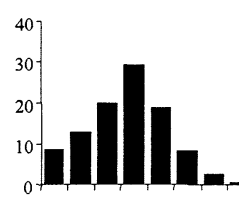

1014182226303438424650

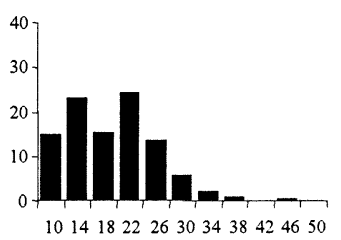

1014182226303438424650

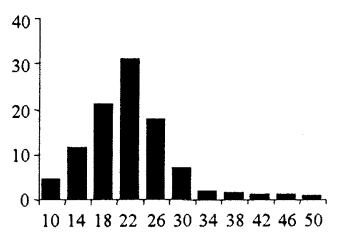

1014182226303438424650

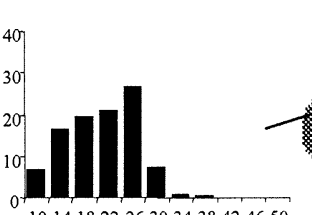

1014182226303438424650
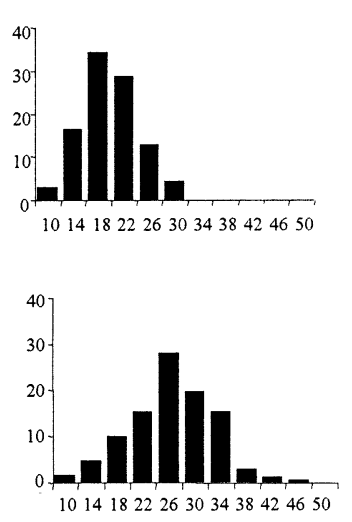
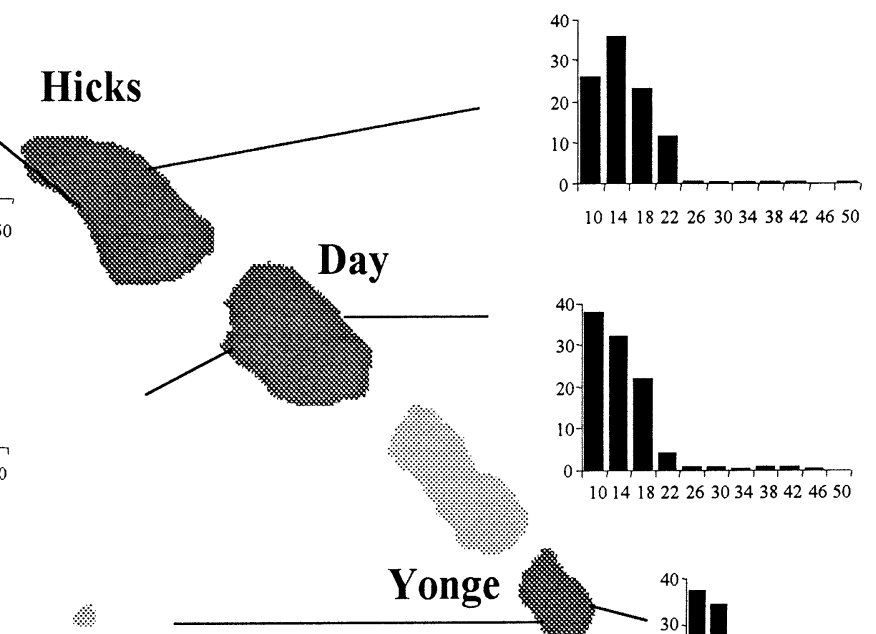

3

Lizard Is.
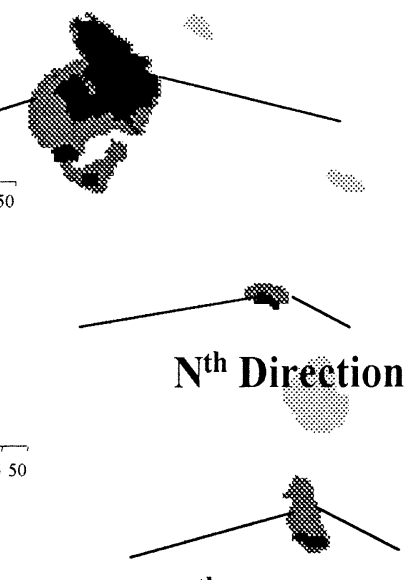

$\mathrm{S}^{\text {th }}$ Direction

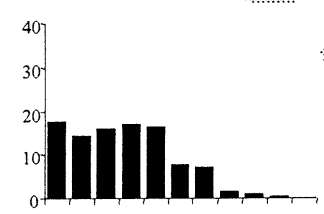

1014182226303438424650

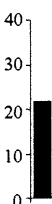

1014182226303438424650

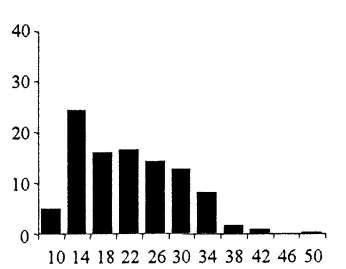

1014182226303438424650
Fig. 10. Size frequency distributions for all scarid species at each study reef. Histograms represent samples pooled from 3 sites on each reef. Histograms on the left are from the sheltered back reef sites of the reefs indicated, while those on the right are from exposed reef crests sites. Mean lengths of each $4 \mathrm{~cm}$ size class are presented on the $x$-axis, while the $y$-axis shows the percentage contribution of each size class in the scarid assemblage 
Table 7. Log-linear analysis of relationships between shelf position, exposure and estimated fork lengths of scarid species across the continental shelf. The most appropriate model in each case is in bold. $\mathrm{N}$ is the number of length estimates obtained for each species. $\left({ }^{*} \mathrm{p}<0.05,{ }^{* *} \mathrm{p}<0.01,{ }^{* * *} \mathrm{p}<0.001\right.$; ${ }^{\mathrm{NS}}$ : nonsignificant). For explanation of the models tested see Table $2 . \mathrm{A}=$ Shelf position, $\mathrm{B}=$ exposure and $\mathrm{C}=$ fork length

\begin{tabular}{|c|c|c|c|c|c|c|c|}
\hline \multirow{2}{*}{$\begin{array}{l}\text { Model } \\
\text { Chloru }\end{array}$} & \multirow[t]{2}{*}{ Factors included } & Deviance & \multirow[t]{2}{*}{ df } & \multicolumn{2}{|c|}{$\begin{array}{c}\text { Difference } \\
\text { between models }\end{array}$} & \multirow[t]{2}{*}{$\begin{array}{c}\text { Change } \\
\text { in df }\end{array}$} & \multirow[t]{2}{*}{$\mathrm{N}$} \\
\hline & & & & & & & \\
\hline 1 & $\mathrm{~A} \times \mathrm{B}+\mathrm{C}$ & 394.4 & 15 & $(1 \& 2)$ & $260.5^{* * *}$ & 5 & 2170 \\
\hline 2 & $\mathrm{~A} \times \mathrm{B}+\mathrm{B} \times \mathrm{C}$ & 133.9 & 10 & $(1 \& 3)$ & $62.7^{* * *}$ & 5 & \\
\hline 3 & $\mathrm{~A} \times \mathrm{B}+\mathrm{A} \times \mathrm{C}$ & 331.7 & 10 & $(2 \& 4)$ & $63.4^{* * *}$ & 5 & \\
\hline 4 & $\mathrm{~A} \times \mathrm{B}+\mathrm{A} \times \mathrm{C}+\mathrm{B} \times \mathrm{C}$ & C 70.5 & 5 & $(4 \& 5)$ & $70.5^{* * *}$ & 5 & \\
\hline 5 & $\mathbf{A} \times \mathbf{B} \times \mathbf{C}$ & 0.0 & 0 & & & & \\
\hline \multicolumn{8}{|c|}{ Scarus altipinnis } \\
\hline 1 & $\mathbf{A} \times \mathbf{B}+\mathbf{C}$ & 25.3 & 21 & $(1 \& 2)$ & $7.0^{\mathrm{NS}}$ & 7 & 113 \\
\hline 2 & $\mathrm{~A} \times \mathrm{B}+\mathrm{B} \times \mathrm{C}$ & 18.3 & 14 & $(1 \& 3)$ & $13.1^{\mathrm{NS}}$ & 7 & \\
\hline 3 & $\mathrm{~A} \times \mathrm{B}+\mathrm{A} \times \mathrm{C}$ & 12.2 & 14 & $(2 \& 4)$ & $5.9^{\mathrm{NS}}$ & 7 & \\
\hline 4 & $\mathrm{~A} \times \mathrm{B}+\mathrm{A} \times \mathrm{C}+\mathrm{B} \times \mathrm{C}$ & 6.3 & 7 & $(4 \& 5)$ & $6.3^{\mathrm{NS}}$ & 7 & \\
\hline 5 & $\mathrm{~A} \times \mathrm{B} \times \mathrm{C}$ & 0.0 & 0 & & & & \\
\hline \multicolumn{8}{|c|}{ S. chameleon } \\
\hline 1 & $\mathrm{~A} \times \mathrm{B}+\mathrm{C}$ & 14.2 & 9 & $(1 \& 2)$ & $2.0^{\mathrm{NS}}$ & 3 & 100 \\
\hline 2 & $\mathrm{~A} \times \mathrm{B}+\mathrm{B} \times \mathrm{C}$ & 12.2 & 6 & $(1 \& 3)$ & $9.9^{*}$ & 3 & \\
\hline 3 & $\mathbf{A} \times \mathbf{B}+\mathbf{A} \times \mathbf{C}$ & 4.3 & 6 & $(2 \& 4)$ & $1.7^{\mathrm{NS}}$ & 3 & \\
\hline 4 & $\mathrm{~A} \times \mathrm{B}+\mathrm{A} \times \mathrm{C}+\mathrm{B} \times \mathrm{C}$ & 2.6 & 3 & $(4 \& 5)$ & $2.6^{\mathrm{NS}}$ & 3 & \\
\hline 5 & $\mathrm{~A} \times \mathrm{B} \times \mathrm{C}$ & 0.0 & 0 & & & & \\
\hline \multicolumn{8}{|c|}{ S. frenatus } \\
\hline 1 & $\mathrm{~A} \times \mathrm{B}+\mathrm{C}$ & 146.7 & 24 & $(1 \& 2)$ & $37.1^{* * *}$ & 8 & 654 \\
\hline 2 & $\mathrm{~A} \times \mathrm{B}+\mathrm{B} \times \mathrm{C}$ & 109.6 & 16 & $(1 \& 3)$ & $61.1^{* * *}$ & 8 & \\
\hline 3 & $\mathrm{~A} \times \mathrm{B}+\mathrm{A} \times \mathrm{C}$ & 85.5 & 16 & $(2 \& 4)$ & $31.2^{* * *}$ & 8 & \\
\hline 4 & $\mathrm{~A} \times \mathrm{B}+\mathrm{A} \times \mathrm{C}+\mathrm{B} \times \mathrm{C}$ & C 54.3 & 8 & $(4 \& 5)$ & $54.3^{* * *}$ & 8 & \\
\hline 5 & $\mathbf{A} \times \mathbf{B} \times \mathbf{C}$ & 0.0 & 0 & & & & \\
\hline \multicolumn{8}{|c|}{ S. globiceps } \\
\hline 1 & $\mathrm{~A} \times \mathrm{B}+\mathrm{C}$ & 246.8 & 12 & $(1 \& 2)$ & $91.7^{* * *}$ & 4 & 883 \\
\hline 2 & $\mathrm{~A} \times \mathrm{B}+\mathrm{B} \times \mathrm{C}$ & 155.0 & 8 & $(1 \& 3)$ & $131.3^{* * *}$ & 4 & \\
\hline 3 & $\mathrm{~A} \times \mathrm{B}+\mathrm{A} \times \mathrm{C}$ & 115.5 & 8 & $(2 \& 4)$ & $104.4^{* * *}$ & 4 & \\
\hline 4 & $\mathrm{~A} \times \mathrm{B}+\mathrm{A} \times \mathrm{C}+\mathrm{B} \times \mathrm{C}$ & C 11.0 & 4 & $(4 \& 5)$ & $11.1^{*}$ & 4 & \\
\hline 5 & $\mathbf{A} \times \mathbf{B} \times \mathbf{C}$ & 0.0 & 0 & & & & \\
\hline \multicolumn{8}{|c|}{ S. niger } \\
\hline 1 & $\mathrm{~A} \times \mathrm{B}+\mathrm{C}$ & 207.0 & 21 & $(1 \& 2)$ & $96.0^{* * *}$ & 7 & 216 \\
\hline 2 & $\mathrm{~A} \times \mathrm{B}+\mathrm{B} \times \mathrm{C}$ & 111.3 & 14 & $(1 \& 3)$ & $95.6^{* * *}$ & 7 & \\
\hline 3 & $\mathrm{~A} \times \mathrm{B}+\mathrm{A} \times \mathrm{C}$ & 111.7 & 14 & $(2 \& 4)$ & $60.5^{* * *}$ & 7 & \\
\hline 4 & $\mathrm{~A} \times \mathrm{B}+\mathrm{A} \times \mathrm{C}+\mathrm{B} \times \mathrm{C}$ & C $\quad 50.8$ & 7 & $(4 \& 5)$ & $50.8^{* * *}$ & 7 & \\
\hline 5 & $\mathbf{A} \times \mathbf{B} \times \mathbf{C}$ & 0.0 & 0 & & & & \\
\hline \multicolumn{8}{|c|}{ S. psittacus } \\
\hline 1 & $\mathrm{~A} \times \mathrm{B}+\mathrm{C}$ & 285.0 & 12 & $(1 \& 2)$ & $139.3^{* * *}$ & 4 & 2626 \\
\hline 2 & $\mathrm{~A} \times \mathrm{B}+\mathrm{B} \times \mathrm{C}$ & 145.7 & 8 & $(1 \& 3)$ & $129.9^{* * *}$ & 4 & \\
\hline 3 & $\mathrm{~A} \times \mathrm{B}+\mathrm{A} \times \mathrm{C}$ & 155.1 & 8 & $(2 \& 4)$ & $100.3^{* * *}$ & 4 & \\
\hline 4 & $\mathrm{~A} \times \mathrm{B}+\mathrm{A} \times \mathrm{C}+\mathrm{B} \times \mathrm{C}$ & C 54.8 & 9 & $(4 \& 5)$ & $54.8^{* * *}$ & 4 & \\
\hline 5 & $\mathbf{A} \times \mathbf{B} \times \mathbf{C}$ & 0.0 & 0 & & & & \\
\hline \multicolumn{8}{|c|}{ S. schlegeli } \\
\hline 1 & $A \times B+C$ & 20.8 & 18 & $(1 \& 2)$ & $4.6^{\mathrm{NS}}$ & 6 & 190 \\
\hline 2 & $\mathrm{~A} \times \mathrm{B}+\mathrm{B} \times \mathrm{C}$ & 16.2 & 12 & $(1 \& 3)$ & $14.4^{*}$ & 6 & \\
\hline 3 & $\mathbf{A} \times \mathbf{B}+\mathbf{A} \times \mathbf{C}$ & 6.4 & 12 & $(2 \& 4)$ & $4.5^{\mathrm{NS}}$ & 6 & \\
\hline 4 & $\mathrm{~A} \times \mathrm{B}+\mathrm{A} \times \mathrm{C}+\mathrm{B} \times \mathrm{C}$ & 1.9 & 6 & $(4 \& 5)$ & $1.9^{\mathrm{NS}}$ & 6 & \\
\hline 5 & $\mathrm{~A} \times \mathrm{B} \times \mathrm{C}$ & 0.0 & 0 & & & & \\
\hline \multicolumn{8}{|c|}{ S. spinus } \\
\hline 1 & $\mathrm{~A} \times \mathrm{B}+\mathrm{C}$ & 32.8 & 18 & $(1 \& 2)$ & $15.2^{*}$ & 6 & 104 \\
\hline 2 & $\mathrm{~A} \times \mathrm{B}+\mathrm{B} \times \mathrm{C}$ & 17.6 & 12 & $(1 \& 3)$ & $15.7^{*}$ & 6 & \\
\hline 3 & $\mathrm{~A} \times \mathrm{B}+\mathrm{A} \times \mathrm{C}$ & 17.1 & 12 & $(2 \& 4)$ & $15.2^{*}$ & 6 & \\
\hline 4 & $\mathbf{A} \times \mathbf{B}+\mathbf{A} \times \mathbf{C}+\mathbf{B} \times \mathbf{C}$ & 1.8 & 6 & $(4 \& 5)$ & $1.8^{\mathrm{NS}}$ & 6 & \\
\hline 5 & $\mathrm{~A} \times \mathrm{B} \times \mathrm{C}$ & 0.0 & 0 & & & & \\
\hline
\end{tabular}

ploitation rates (e.g. Olson 1996). Changes in body size will also commonly influence the strength, type and symmetry of interactions with other species (Werner \& Gilliam 1984), where reduced body sizes on outer shelf reef crests may for instance increase susceptibility to predators (e.g. Caley 1998). Furthermore since female gonad size is strongly influenced by body size in teleosts, we predict that individual female scarids on outer shelf reefs may experience reduced reproductive output in comparison with larger conspecifics on nearby mid shelf reefs.

Depending on the causal mechanisms responsible for reduced body size, cross shelf changes in scarid body size may also have major implications for local population dynamics and local population's responses to disturbance. For instance if density-dependent growth is operating on outer shelf reef crests then we may predict that anthropogenic disturbances, such as fishing, which reduce population densities may facilitate compensatory increases in growth rates in these habitats. However if both higher mortality and recruitment rates prevail for these taxa on outer shelf reefs, we suggest that significant changes in the population dynamics and turnover of local populations could exist across the continental shelf. In addition the changes in body size documented in this study may influence the life history characteristics of individuals across the continental shelf. General life history theory (e.g. Stearns 1992) predicts major changes in the timing of key life history events such as maturation if changes in mortality and growth regimes exist between shelf positions. These potential life history consequences are also currently under investigation.

Acknowledgements. This study was supported by a Lizard Island doctoral fellowship from the Australian Museum awarded to N.G. and a James Cook University prestige grant awarded to M.I.M. Thanks are extended to the staff of the Lizard Island research station for assistance during the course of this study, and in particular for keeping the Condor seaworthy. M. Thomas, 
S. Watson and D. Brown provided invaluable field assistance and we gratefully acknowledge P. Munday for constructive criticism of this manuscript and assistance with log-linear modelling techniques. Thanks also go to D. Williams and 2 anonymous reviewers for constructive criticism of an earlier manuscript.

\section{LITERATURE CITED}

Andrew NL, Mapstone BD (1987) Sampling and the description of spatial pattern in marine biology. Oceanogr Mar Biol Annu Rev 25:39-90

Bell JD, Craik GJS, Pollard DA, Russell BC (1985) Estimating length frequency distributions of large reef fish underwaater. Coral Reefs 4:41-44

Bellwood DR, Alcala AC (1988) The effect of a minimum length specification on visual estimates of density and biomass of coral reef fishes. Coral Reefs 7:23-27

Bellwood DR, Choat JH (1989) A description of the juvenile colour patterns of 24 parrotfish species (family Scaridae) from the Great Barrier Reef, Australia. Rec Aust Mus 41: $1-41$

Bellwood DR, Choat JH (1990) A functional analysis of grazing in parrotfishes (family Scaridae): the ecological implications. Environ Biol Fish 28:189-214

Brown C, Mosteller F (1991) Components of variance. In: Hoaglin DC, Mosteller F, Tukey JW (eds) Fundamentals of exploratory analysis. Wiley, New York, p 59-84

Caley MJ (1998) Age specific mortality rates in reef fishes: evidence and implications. Aust J Ecol 23:241-245

Caley MJ, Carr MH, Hixon MA, Hughes TP, Jones GP, Menge BA (1996) Recruitment and the local dynamics of open marine populations. Annu Rev Ecol Syst 27:477-500

Chabanet P, Letourneur Y (1995) Spatial pattern in of size distribution of four species on Reunion coral reef flats. Hydrobiologia 300-301:299-308

Choat J (1991) The biology of herbivorous fishes on coral reefs. In: Sale PF (ed) The ecology of fishes on coral reefs. Academic Press, San Diego, p 120-155

Choat JH, Randall JE (1986) A review of the parrotfishes (family Scaridae) of the Great Barrier Reef of Australia with description of a new species. Rec Aust Mus 38: $175-228$

Choat JH, Robertson DR (1975) Protogynous hermaphroditism in fishes of the family Scaridae. In: Reinboth R (ed) Intersexuality in the animal kingdom. Springer Verlag, Heidelberg, p 263-283

Clarke RD (1977) Habitat distribution and species diversity of chaetodontid and pomacentrid fishes near Bimini, Bahamas. Mar Biol 40:277-289

Dinesen ZD (1983) Patterns in the distribution of soft corals across the central Great Barrier Reef. Coral Reefs 1: $229-236$

Done TJ (1982) Patterns in the distribution of coral communities across the central Great Barrier Reef. Coral Reefs 1: 95-107

Hammond LS, Birtles RA, Reichelt RE (1985) Holothuroid assemblages on coral reefs across the central section of the Great Barrier Reef. Proc 5th Int Coral Reef Congr 5: 285-290

Hart AM (1996) Response of herbivorous reef fish to outbreaks of crown of thorns starfish, with particular emphasis on the brown surgeonfish (Acanthurus nigrofuscus). $\mathrm{PhD}$ thesis, James Cook University, Townsville

Hughes TP, Baird AH, Dinsdale EA, Moltschaniwskyj NA, Pratchett MS, Tanner JE, Willis BL (1999) Patterns of recruitment and abundance of corals along the Great Barrier Reef. Nature 397:59-63

Jennings S, Polunin NVC (1996) Effects of fishing effort and catch rate upon the structure and biomass of Fijian reef fish communities. J Appl Ecol 33:400-412

Jennings S, Grandcourt EM, Polunin NVC (1995) The effects of fishing on the diversity, biomass and trophic structure of Seychelles fish communities. Coral Reefs 14:225-235

Jennings S, Marshall SS, Polunin NVC (1996) Seychelles' marine protected areas: comparative structure and status of reef fish communities. Biol Conserv 75:201-209

Klumpp DW, McKinnon AD (1992) Community structure, biomass and productivity of epilithic algal communities on the Great Barrier Reef; dynamics at different spatial scales. Mar Ecol Prog Ser 86:77-89

McCook LJ, Price IR, Klumpp DW (1997) Macro algae on the Great Barrier Reef: causes or consequences, indicators or models of reef degradation? Proc 8th Int Coral Reef Symp 2:1851-1856

Meekan MG, Choat JH (1997) Latitudinal variation in abundance of herbivorous fishes: a comparison of temperate and tropical reefs. Mar Biol 128:373-383

Newman SJ, Williams DM (1996) Variation in reef associated assemblages of the Lutjanidae and Lethrinidae at different distances offshore in the central Great Barrier Reef. Environ Biol Fish 46:123-138

Newman SJ, Williams DM, Russ GR (1997) Patterns of zonation of assemblages of the Lutjanidae, Lethrinidae and Serranidae (Epinephelinae) within and among mid shelf and outer shelf reefs in the central Great Barrier Reef. Mar Freshw Res 48:119-128

Olson MH (1996) Ontogenetic niche shifts in large mouth bass - variability and consequences for first year growth. Ecology 77:179-190

Parrish JD (1989) Fish communities of interacting shallow water habitats in tropical oceanic regions. Mar Ecol Prog Ser 58:143-160

Preston NP, Doherty PJ (1990) Cross-shelf patterns in the community structure of coral dwelling Crustacea in the central region of the Great Barrier Reef. 1. Agile shrimps. Mar Ecol Prog Ser 66:47-61

Preston NP, Doherty PJ (1994) Cross-shelf patterns in the community structure of coral dwelling Crustacea in the central region of the Great Barrier Reef. 2. Cryptofauna. Mar Ecol Prog Ser 104:27-38

Quinn G, Keough M (in press) Experimental design and analysis for biologists. Cambridge University Press, Cambridge

Randall JE, Allen GR, Steene RC (1997) Fishes of the Great Barrier Reef and Coral Sea. Crawford House Press, Bathurst

Russ GR (1984a) Distribution and abundance of herbivorous grazing fishes in the central Great Barrier Reef. I. Levels of variability across the entire continental shelf. Mar Ecol Prog Ser 20:23-34

Russ GR (1984b) Distribution and abundance of herbivorous grazing fishes in the central Great Barrier Reef. II. Patterns of zonation of mid-shelf and outer-shelf reefs. Mar Ecol Prog Ser 20:35-44

Russ GR (1985) Effects of protective management on coral reef fishes in the central Philippines. Proc 5th Int Coral Reef Congr 4:219-224

Russ GR, Alcala AC (1998) Natural fishing experiments in marine reserves 1983-1993: roles of life history and fishing intensity in family responses. Coral Reefs 17:399-416

Sale PF (1998) Appropriate spatial scales for studies of reef fish ecology. Aust J Ecol 23:202-208 
Samoilys MA, Carlos G (1992) Development of an underwater visual census method for assessing shallow water reef fish stocks in the south west Pacific. Queensland Department of Primary Industries, Cairns

Scott FJ, Russ GR (1987) Effects of grazing on species composition of the epilithic algal community on coral reefs of the central Great Barrier Reef. Mar Ecol Prog Ser 39:293-304

Sokal RR, Rohlf FJ (1995) Biometry. WH Freeman and Company, New York

Stearns S (1992) Age and size at maturity. In: Stearns S (ed) The evolution of life histories. Oxford University Press, Oxford

St. John J, Russ GR, Gladstone W (1990) Accuracy and bias of visual estimates of numbers, size structure and biomass of a coral reef fish. Mar Ecol Prog Ser 64:253-262

Werner EE, Gilliam JF (1984) The ontogenetic niche and species interactions in size structured populations. Annu Rev Ecol Syst 15:393-425

Wilkinson CR, Cheshire AC (1988) Cross shelf variations in coral reef structure and function - influences of land and

Editorial responsibility: George Humphrey (Contributing

Editor), Sydney, New South Wales, Australia ocean. Proc 6th Int Coral Reef Symp 1:227-233

Wilkinson CR, Trott LA (1985) Light as a factor determining the distribution of sponges across the central Great Barrier Reef. Proc 5th Int Coral Reef Congr 5:125-130

Williams DM (1982) Patterns in the distribution of fish communities across the central Great Barrier Reef. Coral Reefs $1: 35-43$

Williams DM (1983) Longitudinal and latitudinal variation in the structure of reef fish communities. In: Baker JT, Carter RM, Sammarco PW, Stark KP (eds) The inaugural Great Barrier Reef Conference. James Cook University Press, Townsville, p 265-270

Williams DM (1991) Patterns and processes in the distribution of coral reef fishes. In: Sale PF (ed) The ecology of fishes on coral reefs. Academic Press, San Diego, p 437-474

Williams D, Hatcher AI (1983) Structure of fish communities on outer slopes of inshore, mid-shelf and outer shelf reefs of the Great Barrier Reef. Mar Ecol Prog Ser 10:239-250

Wrigley N (1985) Categorical data analysis for geographers and environmental scientists. Longman, London

Submitted: October 3, 1999; Accepted: March 3, 2000

Proofs received from author(s): March 28, 2001 